\title{
Industrial Hemp in North America: Production, Politics and Potential
}

\author{
Jerome H. Cherney ${ }^{1, *}$ and Ernest Small ${ }^{2}$ \\ 1 School of Integrative Plant Science, Soil and Crop Sciences Section, Cornell University, \\ Ithaca, NY 14853, USA \\ 2 Science and Technology Branch, Agriculture and Agri-Food Canada, Ottawa, ON K1A 0C6, Canada; \\ Ernie.Small@AGR.GC.CA \\ * Correspondence: jhc5@cornell.edu; Tel.: +1-607-255-0945; Fax: +1-607-255-2644 \\ Academic Editor: Peter Langridge \\ Received: 9 September 2016; Accepted: 8 November 2016; Published: 12 November 2016
}

\begin{abstract}
Most of the Western World banned the cultivation of Cannabis sativa in the early 20th century because biotypes high in $\Delta^{9}$-tetrahydrocannabinol (THC, the principal intoxicant cannabinoid) are the source of marijuana. Nevertheless, since 1990, dozens of countries have authorized the licensed growth and processing of "industrial hemp" (cultivars with quite low levels of THC). Canada has concentrated on hemp oilseed production, and very recently, Europe changed its emphasis from fiber to oilseed. The USA, historically a major hemp producer, appears on the verge of reintroducing industrial hemp production. This presentation provides updates on various agricultural, scientific, social, and political considerations that impact the commercial hemp industry in the United States and Canada. The most promising scenario for the hemp industry in North America is a continuing focus on oilseed production, as well as cannabidiol (CBD), the principal non-intoxicant cannabinoid considered by many to have substantial medical potential, and currently in great demand as a pharmaceutical. Future success of the industrial hemp industry in North America is heavily dependent on the breeding of more productive oilseed cultivars, the continued development of consumer goods, reasonable but not overly restrictive regulations, and discouragement of overproduction associated with unrealistic enthusiasm. Changing attitudes have generated an unprecedented demand for the cannabis plant and its products, resulting in urgent needs for new legislative, regulatory, and business frameworks, as well as scientific, technological, and agricultural research.
\end{abstract}

Keywords: Cannabis; hemp; marijuana; fiber; oilseed; environmental sustainability

\section{Introduction}

Cannabis sativa L. is usually the only species of Cannabis recognized (and so is often referred to simply as Cannabis in this paper). This species has an extremely long association with humans. It is believed to have been a "camp follower" [1] during the nomadic, pre-agriculture stages of human development, thriving near ancient encampments associated with open areas, well-manured soils, and nearby streams, conditions providing the ideal habitat for the plant. Cannabis is one of the most ancient domesticated crops, cultivated for millennia. In the temperate world, as "hemp", it was cultivated virtually exclusively as a bast (stem) fiber source, and the biotypes grown were so low in $\Delta^{9}$-tetrahydrocannabinol (THC), the principal intoxicating constituent of cannabis plants, that they could not be used as inebriants [2]. By contrast, in southern Asia, C. sativa biotypes were selected that were very high in THC for use as spiritual and recreational drugs. Although only high-THC strains are employed for marijuana, concern over the growing use of the plant for drugs led to most of the Western World banning the cultivation of all forms of C. sativa in the early 20th century. By that 
time, competitive crops (cotton and other tropical fiber plants) had become much more important. Nevertheless, hemp production persisted in some countries, particularly China, where much of the world's hemp for fiber is grown today.

Cannabis contains genetically different biotypes of both industrial (non-intoxicant) hemp and marijuana [2]. "Hemp" or "industrial hemp" will be used interchangeably hereafter to refer to non-intoxicating C. sativa. Industrial hemp is sometimes referred to as "true hemp" to distinguish it from numerous other unrelated plant species that include "hemp" in their common names. Classification of Cannabis as either marijuana or industrial hemp is typically based on a threshold concentration of THC. Although a level of $1 \%$ THC is considered a minimum value to elicit an intoxicating effect, current laws in Canada and several other jurisdictions use $0.3 \%$ THC as the arbitrary threshold point at which cannabinoid content is used to distinguish strains of hemp from marijuana (a criterion first established by Small and Cronquist [3]). Cultivars of hemp must have less than the threshold THC concentration to be grown under license in Western countries permitting hemp cultivation. The European Union originally used a threshold value of $0.8 \%$, later reducing it to $0.3 \%$, and subsequently lowered to $0.2 \%$ THC. The reduction of the EU THC threshold to $0.2 \%$ was ostensibly done in the interests of safety, although $0.3 \%$ is widely accepted as sufficient. Excessive reduction of the criterion, which favors recent French cultivars over other sources, has the undesirable effect of eliminating some useful cultivars (e.g., FINOLA).

While "Cannabis" refers to a taxonomic genus, non-italicized, "cannabis" is a generic abstraction, widely used as a noun and adjective, and commonly (often loosely) used both for cannabis plants and/or any or all of the intoxicant preparations made from them. Note that throughout this review we use the term "intoxicant" in the standard dictionary sense of "inebriant", not implying toxicity as do related words such as "intoxication". However, in its most comprehensive sense "cannabis" also includes non-intoxicant, "industrial" preparations, which could be non-psychoactive medicinal drugs or other useful chemicals, fiber products (such as textiles, plastics and dozens of construction materials) and edible seed products [2].

Seed from industrial hemp is commonly referred to as "hempseed", and the oilseed industry typically refers to the fixed vegetable oil extracted from hempseed as "hempseed oil". Hempseed oil is distinguished from aromatic essential oils distilled from hemp inflorescences and/or foliage, and from "hash oil", an extremely concentrated intoxicating more or less tarry preparation from high-THC strains. Although commonly referred to as a "seed", the fruiting body of hemp is an achene, i.e., a fruit containing a seed. Hulling (i.e., removing the hull) from a hemp achene effectively removes the pericarp, leaving the true seed.

\section{North American History in Brief}

Hemp was cultivated in temperate Eurasia for millennia, and is believed to have been first brought to North America in 1606 [4]. It was grown mainly for fiber in European settlements in Canada and the USA for several hundred years. The industry thrived in Kentucky, Missouri, and Illinois between 1840 and 1860, but was confined to Kentucky from the end of the civil war until around 1912 [5]. In the 1920s, both Agriculture Canada and the US Department of Agriculture (USDA) were still conducting hemp fiber research. During World War I the hemp fiber industry briefly expanded to 12 USA states. There was also a small commercial hemp fiber industry in Canada in the 1920s and early 1930s, mostly in western provinces. In general during the 20th century hemp fiber became much less competitive for rope, apparel, and paper, and became obsolete for a variety of minor uses such as a waterproof packing [2].

In 1938, the Canadian Opium and Narcotics Act made cultivation of all Cannabis illegal. The US Marihuana Tax Act of 1938 did not technically make Cannabis cultivation illegal in the USA, but placed marijuana under control of the USA Treasury Department, requiring permission from the US Drug Enforcement Agency (USDEA) to grow Cannabis. A brief revival of hemp production in both Canada and the USA occurred during World War II, with 68,000 metric tons (MT) of hemp fiber produced 
on 59,000 hectares (ha) in the USA in 1943 (Figure 1) [6], but the 1938 legislation in both countries effectively eliminated hemp production in North America post World War II. One exception was the Rens Hemp Company of Wisconsin which was permitted by USDEA to produce hemp fiber until 1958 [4]. In 1970, the US Congress repealed the 1937 Marijuana Tax Act and replaced it with the Comprehensive Drug Abuse Prevention and Control Act. Although the 1970 Act did create a distinction between marijuana and hemp, USDEA policy following the Act treated marijuana and hemp as the same plant.

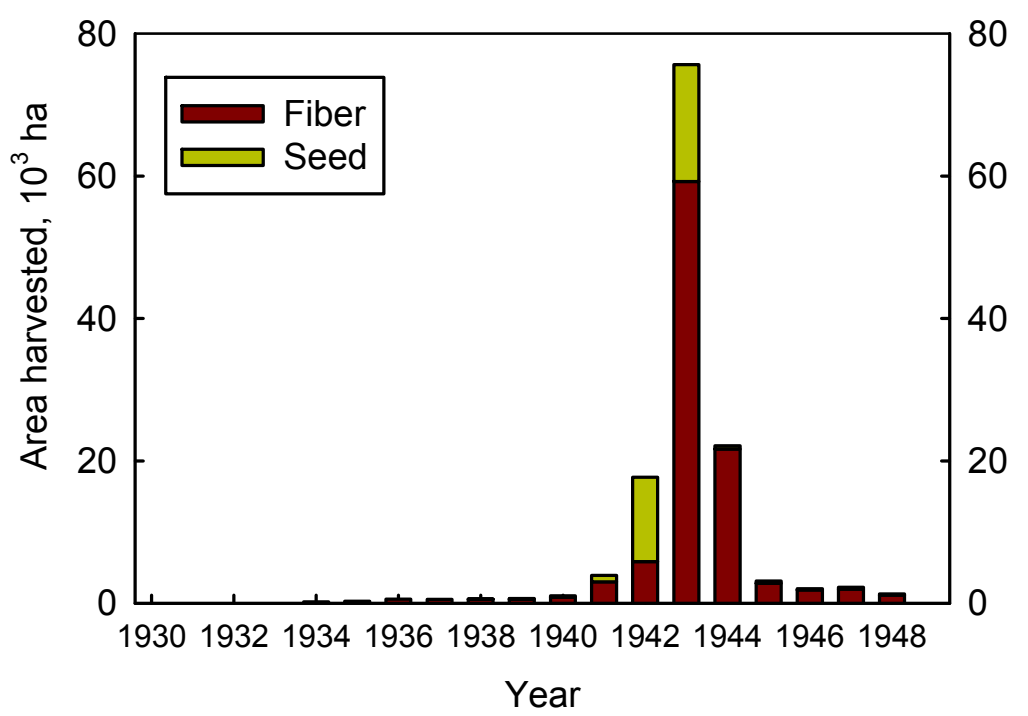

Figure 1. Harvested area (ha) of hemp for fiber and for seed in the USA during the 1930'-s and 1940'-s. Source: [5].

In 1994, Canada started issuing licenses to allow research on industrial hemp. In 1998, new regulations included in the Canadian Controlled Drugs and Substances Act permitted commercial cultivation of hemp, under licensing and control of Health Canada. Section 7606 of the US Agricultural Act of 2014 authorized state departments of agriculture to permit pilot programs for industrial hemp research, although hemp remains classified as a Schedule 1 controlled substance under the USA Controlled Substances Act. Permission from both state departments of agriculture and USDEA are required to evaluate hemp in the USA under strictly controlled conditions.

Cannabis readily escapes from cultivation and establishes as a ruderal plant. After being introduced to North America as a field crop, it gradually spread from the primary areas of cultivation. Today, wild or ruderal Cannabis can be found in most states [6] and provinces [7], but remains more concentrated in southern Ontario and southern Quebec, and in the Midwest and Northeast USA, where hemp cultivation was focused in recent centuries. There have been concentrated efforts by law enforcement to eradicate wild hemp in North America, although it is not an aggressive weed and has virtually no capacity to produce intoxication. However, plants apparently growing wild in parks and wilderness areas are often marijuana strains being illegally cultivated.

\section{Potential Uses for Hemp in North America}

While there are as many as 50,000 uses claimed for hemp products [8], there are only a few hemp products with the potential to generate a significant market. Three major product categories with market potential are: (1) fiber; (2) oilseed; and (3) pharmaceuticals. 


\subsection{Fiber}

Hemp fiber constitutes an outer ring of long phloem fibers ("bast" or "bark") and an inner core of short xylem ("wood") fibers, the former of much greater value than the latter [4]. The inner core of short, stiff, xylem fibers along with remnants of the stem pith are collectively called hemp hurds. The outer primary phloem fibers of the stem grow very long in amalgamated bundles, and are supplemented by secondary phloem tissue produced to the inside of the primary phloem and composed of much shorter fibers. Long bast fibers are valuable, short bast fibers are less valuable, and hurd fibers are about half the value of bast [9]. Separation of bast from hurds is called "retting", with several methods for selectively removing pectic substances that bind the bast fibers to the less desirable parts of the stem. Bast fibers are preferred for automotive applications, and making specialty papers and textiles. Hurd fibers are primarily used for animal bedding and hemp-lime construction applications, and sometimes also for fiberboard [4].

The world hemp fiber market has been relatively stable the past 20 years [10] (Figure 2), even though EU hemp production was reinitiated during this period and fiber production peaked in the late 1990'-s [10] (Figure 3). The FAO data provided in Figure 3 appears to differ substantially from recent European Industrial Hemp Association [11] data for 2013, particularly for hempseed production. European hemp production initially focused on fiber, and the industry has been heavily subsidized by the EU. While synthetic fibers are derived from fossil fuels, natural fibers are extracted directly from plant and animal species, with cotton (Gossypium spp.) and wool as the primary examples, and flax (Linum usitatissiumum L.), sisal (Agave sisalina Perrine), jute (Corchorus sp.), kenaf (Hibiscus cannabinus L.), and abaca (Musa textilis L.) as examples of natural fibers with niche markets. Cotton accounts for about $85 \%$ of the natural fiber textile market worldwide, while hemp accounts for less than $0.5 \%$ [12]. Although hemp pulp is not as profitable as wood pulp, and hemp has more environmental concerns regarding water consumption, soil erosion, and soil nutrient depletion [13], a niche market in Europe has developed for hemp cigarette paper. High quality bast is used along with other natural fibers for a variety of fiber biocomposites for automobiles $[14,15]$. Hemp has about a 15\% market share of the EU automobile biocomposite industry, while about $15 \%$ of the total hemp fiber produced in the EU is used for automobile biocomposites [9].

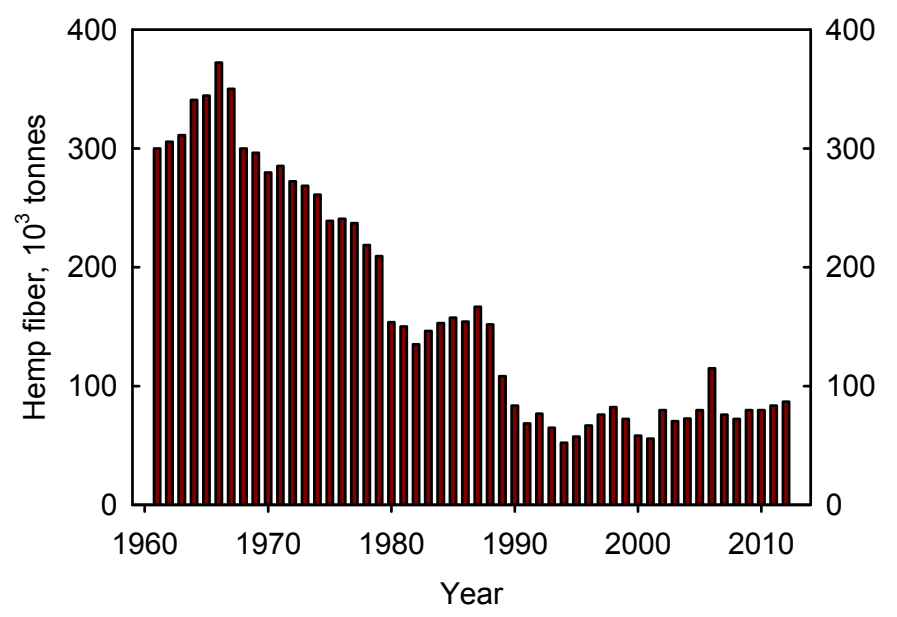

Figure 2. World hemp fiber production, 1961-2013. Source: [10].

From a building materials standpoint, hemp and other natural fibers have light weight, high strength to weight ratio, high insulating potential, and are more recyclable than conventional materials [16]. Hemp-lime construction can include hemp-lime concrete (hempcrete), natural fiber insulation, or hemp-lime stucco, with environmental and economic benefits [17]. Hemp-lime concrete is a mixture of a lime-based binder and relatively inexpensive hemp hurds, and is considered carbon 
negative [18]. Hemp-lime construction is used throughout Europe, but use of hurds for this purpose competes with the lucrative animal bedding market, which uses about half the hurds produced in the EU [9]. Hurds can be an economically viable alternative bedding for both large and small animals [19]. Hemp fiber also has potential as a biomass source, as described later in Section 7.5.

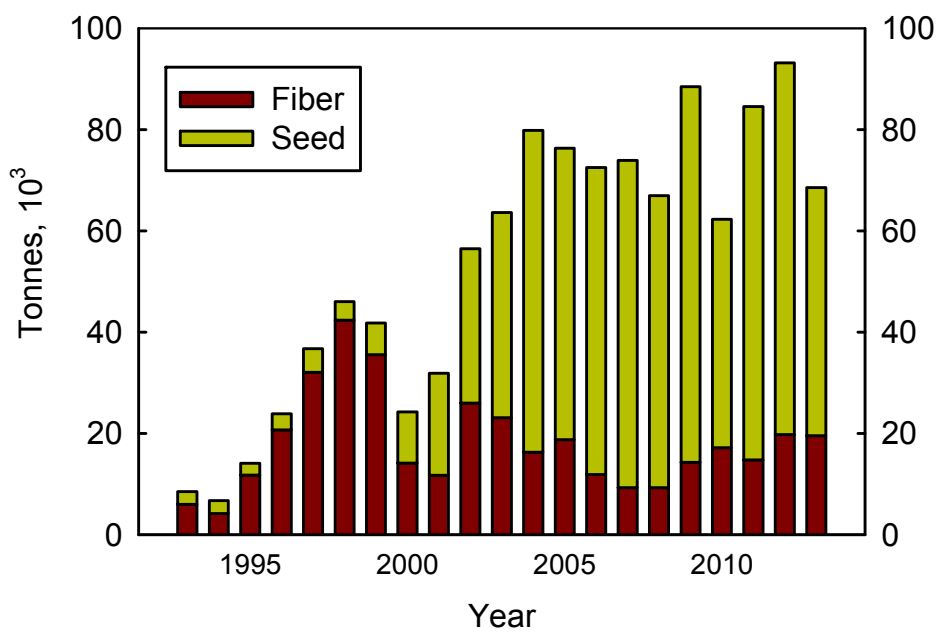

Figure 3. European Union fiber and hempseed production, 1993-2013. Source: [10].

Breeding for fiber has a long history, with relatively modest gains anticipated in the near future. Hemp has limited potential to garner a significant market share as a natural fiber crop. Although there are many applications that can substitute hemp fiber for conventional products, the non-hemp versions are always more economical. Hemp pulp is about five times as expensive as wood pulp in Europe [9]. Cotton likely will remain a more attractive option for apparel. China has well established spinning facilities for natural fibers and coupled with a cheap labor force this makes establishment of a hemp textile industry outside of China problematic. There is a very dedicated niche market for environmentalists interested in hemp building materials, hemp clothes etc., but such uses are not likely to increase greatly. USA imports of hemp yarn have increased over the past couple of years [20] (Figure 4), but in general USA hemp fiber imports are relatively stagnant compared to hempseed imports (Figure 5). Even with significant subsidies, European hemp fiber production has not greatly expanded, and it is highly unlikely that either Canada or the USA would consider any form of hemp subsidy.

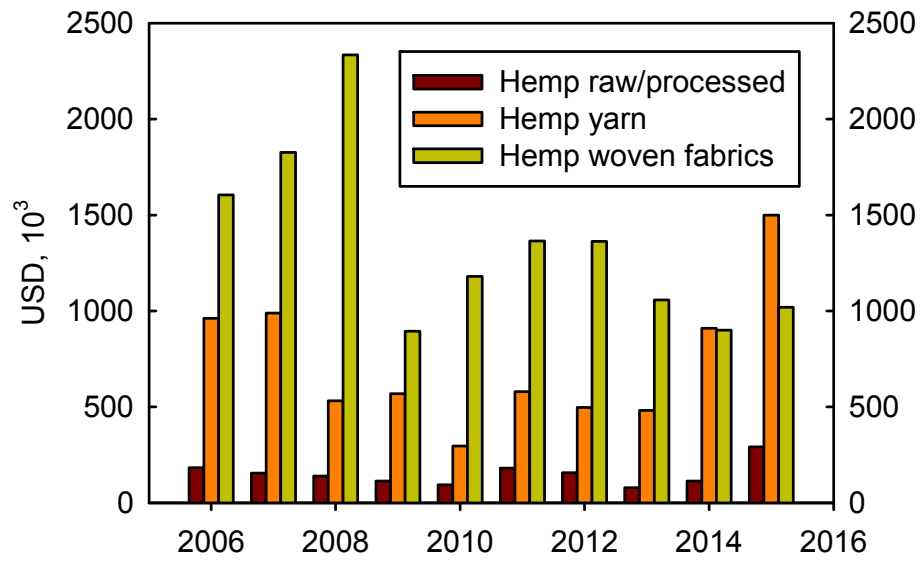

Figure 4. Value (USD) of USA imports of hemp fiber products, 2006-2015. Source: [20]. 


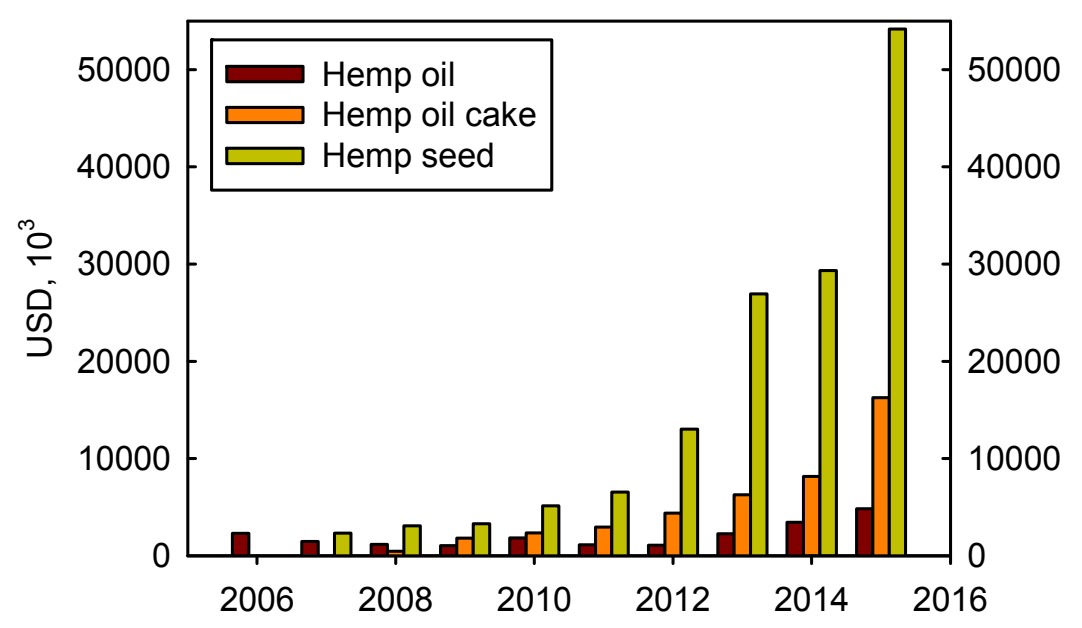

Figure 5. Value (USD) of USA imports of hempseed and hemp oil products, 2006-2015. Source: [20].

\subsection{Oilseed}

Hempseed has been used as food for at least 3000 years for both humans and livestock [12], and hempseed was one of the "five grains" of ancient China [21]. Hemp oil was also used as a lighting oil, and for making soap, paints and varnishes in the past. Twentieth century usage of the grain was confined mostly to bird seed, and oilseed land races of hemp were abandoned. Relatively recently, oilseed cultivars were bred in both Europe and Canada [22]. There is limited evidence that significant domestication occurred in the past specifically for harvest of seeds for human consumption, although a few land races in China have large seeds used as snack food. By comparison, most domestication for low-THC hemp was for fiber characteristics. In the last two decades, there has been increased selection specifically for seeds, and the few cultivars that have been developed represent only a limited amount of the potential for oilseed qualities and productivity. Hulled hemp seed, canned or vacuum-packed, recently has become a popular food for human consumption. The gritless seed meal produced by hulling differs from the oil-poor seed cake remaining after oil has been expressed, which also has been referred to as seed meal [4].

Vegetable oils extracted from seeds can be used as food, biofuel, nutritional supplements, and a wide variety of industrial applications. However, at present hempseed and hempseed oil is economically significant mostly as a minor specialty crop furnishing a niche food market. About $90 \%$ of the edible oil production worldwide comes from palm (Arecaceae spp,), soybean (Glycine max (L.) Merr.), canola (Brassica napus) and sunflower (Helianthus annuus L.) [23]. Hempseed oil can be pressure-extracted on either a small or large scale, using screw or hydraulic presses, which extract $60 \%-80 \%$ of the oil [24]. The residual pumace can be pressed into an 'oil cake' (seed cake) which in reality is a de-oiled cake. The protein-rich seed cake remaining after oil has been expressed has been shown to be an excellent livestock feed [25]. Hempseed oil also can be extracted with $n$-hexane solvents [26], although this typically results in a contaminated final product unsuitable for human food or animal feed [27]. It is possible to use supercritical $\mathrm{CO}_{2}$ extraction to produce food quality hempseed oil [28], but it is costly and time consuming.

Hempseed oil is a vegetable or fixed oil from the seed (achene), and is best used as a fresh uncooked (salad) oil. The smoke point of hempseed oil is approximately $165^{\circ} \mathrm{C}$, which is too low for high temperature cooking or frying [12]. Approximately $80 \%$ of the fatty acids in hempseed oil are unsaturated [29], giving it a relatively short shelf life, which can be extended by storing in dark containers and by refrigeration.

Hempseed oil is rich in both omega- 6 and omega- 3 essential fatty acids, with a ratio of omega- 6 to omega-3 considered optimal for human health [22,29]. Hempseed oil contains significant quantities of $\gamma$-linolenic acid (GLA), and smaller concentrations of other fatty acids of dietary significance [30]. 
Aging, diet and pathology may impair GLA metabolism, and supplementation in the diet can have a positive effect on many disorders [31]. Antioxidant tocopherols of the Vitamin E group are present in hempseed at higher concentrations than flax and canola seed oils [32], with about $80 \%$ of tocopherol present as $\gamma$-tocopherol [24,33]. Sterols up to about $0.7 \%$ of the oil are present in hempseed oil [24], and have a desirable antioxidant function. Phenolic compounds also are effective antioxidants providing cardio-protection and anti-inflammation benefits. Hempseed is rich in phenolics, with almost a four-fold range in concentration among current cultivars [34].

As with any grain crop, the primary breeding goal is increased yield, which must include selection to reduce seed shattering. Most breeding for oilseed characteristics has taken place in the past decade and it is likely that significant advances in oilseed composition can be made in the near future [12]. Oilseed characteristics of accessions and cultivars have been evaluated in Canada [35], China [36], Germany [37], Pakistan [38], and Romania [39]. One essential goal of any breeding program is to keep THC levels as low as possible. The United Kingdom prohibited marketing of the very popular oilseed cultivar, FINOLA, in January 2016 for exceeding the authorized THC content two years in a row [40], however the European Commission decision to authorize the prohibition was recently repealed [41]. It appears that a number of compositional traits are significantly influenced by environment, particularly latitude. Mölleken and Theimer [42] determined that hempseed grown in northern regions has a much higher concentration of GLA, compared to hempseed from more southern regions.

Currently, oilseed hemp is not competitive with linseed (Linum usitatissimum) for manufacturing oil, neither is it competitive with sunflower or canola for edible vegetable oil [12]. Nevertheless, economic prospects for a hemp oilseed crop in North America are promising, as the demand for hempseed products (seed, oil, and oil cake) is steadily increasing [20] (Figure 5). USA hempseed imports increased from $\$ 29$ million in 2014 to $\$ 54$ million in 2015, and hemp oil cake imports doubled over that period to $\$ 16$ million. Total USA imports of seed, oil, and oil cake products exceeded $\$ 75$ million in 2015. Hempseed production in the European Union (EU) has increased greatly [10] (Figure 3), and was as high as 73,450 tonnes in 2012. However, unlike Canada where hempseed is mainly employed as human food, in Europe the seed has been predominantly employed as livestock feed.

\subsection{Pharmaceuticals}

Cannabis contains a relatively unique class of terpenophenolic compounds-the cannabinoids. There are well over 100 different cannabinoids [43] produced in epidermal trichomes, but few are present in appreciable quantities, and relatively few have adequate pharmacological data available. Trichomes are epidermal appendages present on aerial parts in most plant species with many proposed functions, usually considered protection against predators [44,45]. There are several classes of epidermal secretory glandular trichomes in Cannabis, all of which produce cannabinoids [46]. Most THC is located in the resin heads of capitate-stalked glandular trichomes [47]. The highest concentration of cannabinoid resin is found in trichomes on the perigonal bracts which envelop the pistils and seeds. Glandular trichomes are also concentrated on the lower surface of young leaves, and on sepals and anthers. The primary cannabinoids produced in glandular trichomes are shown in Figure 6. The non-intoxicant cannabigerol (CBG) is the precursor of the other cannabinoids. Cannabichromene $(\mathrm{CBC})$ is a non-intoxicant type found in trace amounts. There is generally an inverse relationship between THC and CBD in Cannabis; marijuana types produce primarily THC, while industrial hemp types produce primarily CBD [12]. Moreover, marijuana biotypes produce considerably more cannabinoids than do industrial hemp cultivars. Cannabidiol (CBD) antagonizes the intoxicant effects of THC [48]. Cannabinol (CBN) is a degradation product (Figure 6), not found in appreciable quantity in fresh plants. The THC in stored marijuana gradually converts over time to CBN, which is estimated to have $10 \%$ of the psychoactive potential of THC [49]. Cannabidiol can be converted to THC by acid catalyzed cyclization, but this is not a practical method for generating THC. 


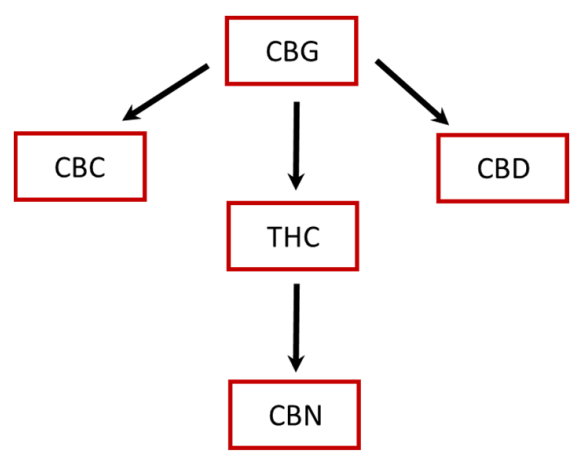

Figure 6. Biosynthetic pathways of the principal cannabinoids. $\mathrm{CBG}=$ cannabigerol; $\mathrm{CBC}=$ cannabichromene; $\mathrm{CBD}=$ cannabidiol; $\mathrm{THC}=\Delta^{9}$-tetrahydrocannabinol; $\mathrm{CBN}=$ cannabinol.

Marijuana is chemically characterized by high amounts of THC while hemp is characterized by high amounts of CBD, but the psychopharmacological distinction between THC and CBD is somewhat problematical. As discussed by Small [12], the pharmacological classification of marijuana is controversial, and numerous terms have been applied to it and to THC in particular. These include psychedelic (mind-manifesting or consciousness-expanding), hallucinogenic (hallucination-producing), psychotomimetic (psychosis-imitating), illusinogenic (illusion-producing), psychodysleptic (mind-disrupting), psychoactive (altering sensation, mood, consciousness or other psychological or behavioral functions), psychotropic (mind-altering), and psychotomimetic (mood-altering). Several of these terms apply to CBD, not just to THC. A psychoactive drug acts primarily upon the central nervous system where it alters brain function, resulting in temporary changes in perception, mood, consciousness and emotion. A psychoactive drug is a psychotropic substance. Since CBD has anti-anxiety, anti-psychotic, and anti-depressant effects, it is correctly considered a psychoactive drug [50].

Cannabidiol was first isolated from Cannabis in the late 1930s [51], and has since been found to have therapeutic potential for disorders such as inflammation and anxiety, and also has potential as a neuroprotective agent and an antioxidant [52,53]. Along with CBD, other minor cannabinoids such as cannabidiolic acid (CBDA), tetrahydrocannabinolic acid (THCA), and cannabidivarin (CBDV) have shown efficacy for relief of nausea and emesis [54]. Cannabidiol also has been used to treat arthritis, cancer, diabetes, neurodegenerative diseases and pain [23]. Indeed, CBD has many more medical applications than THC [23], and since CBD is the principal cannabinoid of hemp it is arbitrary to refer only to high-THC biotypes of $C$. sativa as "medical cannabis". Oilseed cultivars produce more flowers than fiber cultivars, and since the principle source of resin is from flowering tops, oilseed cultivars are a much more promising source of CBD than fiber cultivars [55]. At present, however, selected biotypes are being employed to produce $\mathrm{CBD}$ commercially_strains that not only produce mostly CBD by comparison with the yield of THC, but also produce much more $\mathrm{CBD}$ than conventional industrial hemp cultivars.

\section{Lessons from Novel Field Crops in North America in Recent Decades}

Hempseed production has been relatively successful in Canada. There are numerous claims that industrial hemp could transform the economy of the USA in a beneficial way, but it is worth keeping in mind that there has often been excessive enthusiasm for "new", "diversification", or "novel" crops. While there is apparently good potential for expansion of the hemp industry in North America, this also has thought to have been the case for many novel field crops over the past 50 years. There have been very optimistic claims for a number of crops publicized as having remarkable potential, but very few if any actually reached that potential (Table 1). Some of them have experienced little research and development, although most have surfaced in multiple decades of recurrent interest. Novel crops are often region-specific and best suited to a particular environmental niche. There are 
a few novel field crops suitable for growing across many different soil environments in multiple regions of North America. Some of these are annual crops that are not subject to winter conditions, while a few are perennial crops that have evolved ecotypes over decades or centuries that are better adapted to local environmental conditions. The most outstanding example for perennials is switchgrass (Panicum virgatum L.), with ecotypes evolved to fit a wide range of geographical diversity [56].

Crops such as camelina (Camelina sativa (L.) Crantz), kenaf (Hibiscus cannabinus L., Malvaceae), meadowfoam (Limnanthes alba Benth.), and teff (Eragrostis tef (Zucc.) Trotter) have all received some USA federal funding to hasten development and expansion of these crops, but acreage is shrinking due to a lack of market interest for all but teff. Novel crops primarily used for forage, such as comfrey (Symphytum spp.) and kura clover (Trifolium ambiguum M. Bieb.), typically do not receive any funding assistance and interest fades. An exception is brown-midrib (BMR), reduced lignin mutants, such as BMR pearl millet [Pennisetum glaucum (L.) R. Br.] [57]. Commercial interest over decades gradually resulted in research and development, and eventually led to niche markets for BMR pearl millet, BMR sorghum $\times$ sudangrass $($ Sorghum bicolor $($ L.) Moench) $\times$ (Sorghum sudanense Piper), and BMR corn (Zea mays L.).

The most infamous example of a novel field crop promotion prior to an established market was Jerusalem artichoke (Helianthus tuberosus L.). In the 1980s, midwestern USA farmers were assured that there would be a market for the tuber and were convinced to plant a relatively large area to the crop in an agricultural pyramid scheme spanning several years [58]. Profits were realized by the original distributors and a few of the initial farmers, who sold seeds to subsequent levels of the pyramid. A market never materialized and most of the crop was ruined and production abruptly terminated.

While USA federal funding assistance has helped some of the novel field crops in Table 1 reach a niche market status, even massive federal funding assistance in the case of biomass crops has not resulted in widespread production, simply due to the shortage of market demand. For the novel field crops in Table 1, we are requiring production in excess of 1000 ha in North America to consider it a niche market. The Biomass Crop Assistance Program (BCAP) was created by the US Congress in 2008 to meet the feedstock challenges of an expanding commercial-scale cellulosic biofuel industry, but "numerous headwinds continue to retard the development of that industry." [59]. Funding for BCAP peaked at nearly $\$ 250$ million in 2010, reduced to $\$ 11.5$ million in 2015 . While there is a considerable area of switchgrass grown for conservation or forage uses, most of the USA switchgrass and Miscanthus (Miscanthus $\times$ giganteus J. M. Greef and Deuter ex Hodk. and Renvoize) acreage grown for biomass is subsidized by BCAP. No amount of general public interest or funding support for a novel crop will overcome the lack of a market for its products.

Industrial hemp is one of the novel annual field crops with a relatively wide range of adaptation across North America. While it is possible for wild-growing Cannabis to survive in any province or state, domesticated cultivars of hemp are less stress tolerant [7]. Producing economic yields of hemp fiber or seed requires a moderate climate with a productive soil and plenty of water. Novel crops typically have agronomic, processing/conversion, economic, and/or social issues that prevent them from achieving their potential, and hemp faces all these issues to some extent. Although USA federal funding assistance has ranged from none to massive amounts for novel field crops, none of these crops have yet to achieve widespread adoption across the country. It is unlikely that hemp production would be significantly subsidized in either Canada or the USA. Although no barriers exist for USA multinationals to invest in hemp elsewhere, such investment has been minimal [60]. 
Table 1. Status of selected novel field crops in North America

\begin{tabular}{|c|c|c|c|c|c|c|c|c|}
\hline & Region in & Research & & & 2015 & NA & Year of Peak & USA Federal \\
\hline Field Crop & USA/Canada & Decades & Product & Most Optimistic Claims & Area, ha ${ }^{1}$ & Status $^{2}$ & Production, ha $^{3}$ & Assistance \\
\hline BMR Pearl millet, annual & USA & $1980 / 2000$ & Forage & Highly digestible summer forage & 20,000 & 4 & 2015 & No \\
\hline Pennisetum glaucum (L.) R.Br. & S Canada & & & & NR & & & \\
\hline Camelina, annual & N USA & 1960/1980 & Oilseed & Omega-3 oil & 1392 & $2,3,4$ & 2007: 9700 & Yes \\
\hline Camelina sativa (L.) Crantz & S Canada & 2000 & & & NR & & & \\
\hline Comfrey, annual & NC USA & $1910 / 1980$ & Forage/medicinal & Tremendous yields/medicinal & NR & $1,2,3$ & none & No \\
\hline Symphytum spp. & Canada & & & value & NR & & & \\
\hline Grain amaranth, annual & NC USA & 1970-1980 & Pseudo-grain & Food of the Aztecs & 153 & 1,3 & 1988: 1200 & No \\
\hline Amaranthus spp. & S Ontario & 1990 & & & NR & & & \\
\hline Industrial hemp, annual & N 3/4 USA & $1840 / 2010$ & Oilseed/fiber & Humankind's savior & 621 & $1,2,3,4$ & 1943: 59,200 & No \\
\hline Cannabis sativa $\mathrm{L}$. & S Canada & $1920 / 2010$ & & & 34,263 & & 2014: 43,909 & \\
\hline Jerusalem artichoke, annual & NC USA & $1930 / 1980$ & Tuber & Manna of the plains & NR & 2,3 & 1982: 4000 & No \\
\hline Helianthus tuberosus L. & SE Canada & 1980 & & & NR & & & \\
\hline Kenaf, annual & S USA & 1940-1990 & Fiber/oilseed & Most promising non-wood fiber & 206 & $1,2,3$ & 2000: 7300 & Yes \\
\hline Hibiscus cannabinus L. & S Ontario & 2010 & & & NR & & & \\
\hline Kura clover, perennial & N USA & $1910 / 1980$ & Forage & Potential to be major forage & NR & 1 & none & No \\
\hline Trifolium ambiguum M. Bieb. & Canada & 1990 & & crop & NR & & & \\
\hline Meadowfoam, annual & NW USA & $1980 / 2000$ & Oilseed & Tremendous potential & 692 & 1,3 & 2012: 789 & Yes \\
\hline Limnanthes albal Benth. & SW Canada & & & & NR & & & \\
\hline Miscanthus, perennial & E $1 / 2$ USA & 2000-2010 & Biomass & Highest yielding biomass crop & 7400 & $1,2,3,4$ & 2015 & Yes \\
\hline Miscanthus $\times$ giganteus & SE Canada & 2010 & & & 120 & & & \\
\hline Quinoa, annual & NW USA & $1980 / 2010$ & Pseudo-grain & Nutrient-dense superfood & 224 & $1,2,4$ & 2015 & No \\
\hline Chenopodium quinoa Willd. & SW Canada & 1990 & & & $<2000$ & & & \\
\hline Spelt, annual & N 2/3 USA & $1890 / 1980$ & Grain & Alternative to wheat & 6081 & 4 & 1980: 81,000 & No \\
\hline Triticum aestivum var. spelta & S Canada & & & & $<5000$ & & & \\
\hline Sunn hemp, annual & S $2 / 3$ USA & $1930 / 1980$ & Fiber & Excellent cover crop & 343 & 1 & 2015 & No \\
\hline Crotalaria juncea L. & S Ontario & & & & NR & & & \\
\hline Switchgrass, perennial & USA & 1980-2010 & Biomass/forage & Model bioenergy crop & $>5000$ & $2,3,4$ & 2015 & Yes \\
\hline Panicum virgatum L. & SE Canada & $2000-2010$ & & & 1800 & & & \\
\hline Teff, annual & USA & 1990 & Grain/forage & New superfood & 10,818 & $1,2,3,4$ & 2015 & Yes \\
\hline Eragrostis tef (Zucc.) Trotter & S Canada & & & & NR & & & \\
\hline
\end{tabular}

Eragrostis tef (Zucc.) Trotter S Canada

NR = Not reported or too little to report. Seed company estimates if no official crop statistics; ${ }^{2} 1=$ Agronomic issues; $2=$ Conversion $/$ processing issues; $3=$ Market issues

$4=$ Has niche market; ${ }^{3}$ Year of peak production, if known. 


\section{Hemp Production in North America}

Detailed agronomic recommendations for Kentucky and Ontario [61,62] are available in the literature and key points are summarized here. Only hemp cultivars approved by Health Canada are allowed to be planted commercially in Canada. These cultivars mostly originated from Europe, although there is very recent breeding of oilseed cultivars in North America. The cultivar FINOLA has become the most popular cultivar grown in Canada. While some current cultivars will most likely prove adequate in some regions of the USA, there will be a need to develop cultivars better suited to specific regions and climates. Along with breeding for improved seed or fiber yields, it will remain critical for all cultivars to produce plants containing less than $0.3 \%$ THC. Dioecious, monecious, and female dominant cultivars are available. Commercial seed stocks of so-called monoecious cultivars typically develop plants with both male and female flowers, although some plants have exclusively male or exclusively female flowers [23]. Commercial seed stocks of female-dominant cultivars predominantly produce plants with female flowers.

Soils ideally suited to hemp production are comparable to corn-growing soils: they are well-aerated loams with high fertility and high organic matter. Marginal types of soil that are unproductive, compacted or poorly-drained are inappropriate. Fertility requirements for hemp production are similar to a high-yielding crop of wheat, with up to $110 \mathrm{~kg} \cdot \mathrm{N} \cdot \mathrm{ha}^{-1}$ suggested [62]. For fiber production, seeds are normally sown in rows spaced from 7 to $20 \mathrm{~cm}$ apart. For seed production in Europe, seeds have been planted in rows spaced $15-18 \mathrm{~cm}$ apart, but closer planting is best for the popular but quite short cultivar FINOLA. Detailed information on agronomics of FINOLA is available [63]. Seeding depth should not exceed $3 \mathrm{~cm}$, and seeding rate is very cultivar specific and varies widely. Fiber cultivars are seeded at 45 to $70 \mathrm{~kg} \cdot \mathrm{ha}^{-1}$, while oilseed cultivar seeding rates range from 10 to $45 \mathrm{~kg} \cdot \mathrm{ha}^{-1}$ [4]. Hemp in a continuous monoculture risks buildup of weeds and insect pests [64] and a four-year crop rotation with hemp grown for one year is recommended.

Most hemp cultivars are photoperiodic, and for these the earlier the planting date, the more vegetative growth that will accumulate, as hemp is day-length sensitive and flowering is triggered with the onset of shorter days in late July [4]. However, FINOLA, the most widely grown cultivar, is day-length insensitive ("day neutral", "autoflowering"), although drought will hasten maturation. A fiber crop of hemp is harvested in the early flowering stage, and retting of the fiber is usually done in the field, requiring several weeks. Fiber can be baled with conventional equipment at around $15 \%$ moisture, and bales must be stored indoors. Hempseed is harvested when seed starts to shatter from the indeterminate inflorescence, when about $70 \%$ of the seed is ripe [4]. Short cultivars are the easiest to combine and minimize machinery wear [4]. By far, birds are the greatest pests for hempseed production in North America, and can be devastating in small fields of hemp.

In Canada, hemp production occurs from eastern to western Canada, but is concentrated in the prairie provinces. The Corn Belt is likely the best region in the USA for hemp production [4], although Kentucky has had very good success with hemp in the past. The requirement for good soils, relatively abundant rainfall, and a moderate climate will restrict opportunities for hemp production in the southeastern, southwestern and western USA. Soil requirements may eliminate a large percentage of cropland in the northeastern USA from potential hemp production, due to marginal, inadequately-drained soils.

\section{Environmental Impact}

\subsection{Biodiversity}

Montford and Small $[65,66]$ proposed a biodiversity friendliness index with 26 parameters with either negative or positive effects on biodiversity and/or the environment, and applied it to a selected group of major crop species. Hempseed production ranked highly, exceeded as a field crop only by alfalfa (Medicago sativa L.), although alfalfa was the only perennial forage crop included in the example comparison. Hemp does have many positive biodiversity features relative to other annual row crops, 
but does not compare well to perennial or winter annual forage sod crops that are often composed of multiple species, including Nitrogen-fixing legumes. Hemp is a weedy crop by nature, escaping easily, and weeds reduce biodiversity. On the positive side, hemp does not require pesticides, which reduce soil organism biodiversity and may threaten survival of some species. Hemp also produces environmentally-friendly manufactured products, as well as beneficial products for wildlife.

\subsection{Environmental Sustainability}

The environmental benefits of hemp are often exaggerated in the popular press; hemp is not "the key to our green future". Hemp is an annual row crop and as such is susceptible to significant soil erosion and soil nutrient depletion, and also has a relatively high water requirement. In particular, the relatively high nitrogen $(\mathrm{N})$, phosphorus $(\mathrm{P})$, and potassium $(\mathrm{K})$ requirements of a hempseed crop tend to refute the excessive sustainability claims for hemp. Hemp is naturally adapted to employing mammalian manure as fertilizer, and was generously fertilized with manure in past times. It has the potential of efficiently employing stocks of livestock manure, although synthetic fertilizers, which are less desirable from a sustainability perspective, are usually employed in developed nations. One of the primary environmental claims for hemp is the potential to save trees, but da Siva et al. [13] concluded that hemp fiber presents higher environmental impacts than eucalyptus paper in all of the environmental categories they analyzed. However, hemp produces environmentally-friendly manufactured products, including thermal insulation, carbon-sequestering bioplastics, and lightweight concrete substitutes that reduce transportation costs [23]. Hemp does have a deep root system that decays rapidly to provide both soil aeration and fertilization.

Hemp provides both food and fiber which put it in the essential category for human survival, as opposed to luxury or non-essential crops. Hemp fiber products such as wool, fiber panels, cement and plastics can fix carbon for relatively long periods [67], but these uses are likely to remain a very small portion of the total market. Hemp does have potential as a soil bio-remediation crop [68]. Since North American hemp production and processing will involve relatively high fertilizer inputs, as well as machinery in place of the manual labor used in other countries, the energy to produce and process the crop will be significant.

\section{Economics}

\subsection{Economic Forecasts}

When it became evident during the last decade of the twentieth century that hemp cultivation was being promoted, several economic analyses were conducted in various countries $[55,69-76]$. Vantreese [60] noted that without a viable processing industry, profit projections for USA-grown hemp were extremely speculative. In 2000, USDA Economic Research Service [77] concluded that hemp markets are likely to remain small, and uncertainty about long-term demand and the potential for oversupply minimized the chance for hemp as an economically viable alternative crop in the USA. These analyses are more or less obsolescent, since hemp cultivation has actually been revived in many countries, and the resulting hemp products have been tested in the marketplace for the last two decades. Fortenbery and Bennett [78] concluded that hemp is slightly more profitable than traditional grain crops, but less profitable than specialty crops, and on the whole is rather discouraging of future development. Robbins et al. [79] examines the potential in Kentucky. Johnson [80] concluded that small scale, profitable niche markets for hemp products could make hemp an economically viable alternative crop for some regions of the USA. Recent reviews are clearly relatively optimistic. Hemp is now grown commercially in about three dozen countries, with the notable exception of the United States (although this seems about to change). Earlier economic analyses generally failed to foresee that hempseed rather than fiber applications would become the most promising aspect of industrial hemp development. A variety of imaginative, innovative hemp fiber and hempseed products have appeared 
in the marketplace in the last two decades, and have provided considerable impetus to increasingly promising industries [4].

\subsection{Fiber}

In past centuries, hemp was a leading cordage and textile crop, but with the advent of cotton, tropical fiber crops and modern synthetic fibers, such uses are confined to a niche market, attractive to a small number of consumers who like the "green image" and marijuana association of the plant. China, the world's leading producer of hemp, has an established tradition of producing high-quality textile-grade fiber and textile products [23]. China's hemp fiber industry has the advantages of cheap labor and regulatory tolerance of water retting, which is environmentally unacceptable in most of the West. Attempts to re-establish a hemp textile industry in Europe using new technology have not been cost-effective to date, and it is likely that China will remain dominant in the foreseeable future in producing high-quality hemp textiles for apparel.

In Europe in the last two decades, there has been an economic resurgence of hemp fiber in the marketplace, based on non-traditional usages, particularly in the production of a very wide range of pressed fiber and insulation products, and plastics. In Europe, the greatest success of hemp fiber products has been in the automobile, construction, and agriculture industries [23]. Although hemp fiber has superior characteristics for particular applications, market penetration has been due, in substantial part, to subsidization (related to "green support" policies). With the diminishment of such support, the future success of such products is uncertain. A major economic concern of growing hemp for fiber is the cost of transportation to a processing center. As found with most biomass energy crops, hemp is a bulky crop and it is not cost-effective to ship hemp far from a processing plant. The Illinois Hemp Task Force [81] noted that a processing plant for hemp fiber needs to be a maximum of $80 \mathrm{~km}$ away.

\subsection{Oilseed}

Hemp has far more potential as an oilseed crop than as a fiber source. Canada has become the leading country of hempseed production since industrial hemp was reintroduced in the country in 1998. In Europe, some dual purpose cultivars (harvested for both oilseed and fiber) have been cultivated. However, it is clear that this compromises the quality of the two crops. In very recent times, the EU has realized that its investment in fiber hemp has been a miscalculation, and it is investing in oilseed hemp. According to Bio-based News [82] "A hemp seed market potential linked to a penetration of $5 \%$ of the European nut market would signify an added market value of $€ 1$ billion/year (\$1.14 billion/year)".

The dietary advantages of hempseed and hempseed oil are quickly gaining acknowledgment in North America, and sales of hempseed products are rapidly increasing. China can produce relatively inexpensive hempseed, but imported seed must be sterilized, which adds cost and lowers grain quality. Traditional use of hempseed oil for manufacturing of paints and lubricants is obsolete. Since most hempseed is now grown for human consumption, and the seed and oil have limited shelf life, domestic production is advantageous to avoid rancidity prior to consumption [23]. Also, there is a rapidly growing market for organically-produced foods in North America, and organic certification of hempseed from outside North America is problematic.

The key need of the oilseed hemp industry is the development of high-yielding cultivars to increase the competiveness of hempseed in relation to other oilseeds. The present productivity of oilseed hemp-about 1 tonne/ha under good conditions, occasionally 1.5 to 2 tonnes/ha, is not yet sufficient for the crop to become competitive with major oilseeds. An average productivity of at least 2 tonnes/ha will be necessary to transform hempseed into a major oilseed, and this breeding goal is achievable. At present, losses of $30 \%$ of the seed yields are not uncommon, so that improvements in harvesting technology should also contribute to higher yields [4]. Hemp food products cannot escape their niche market status until the price of hempseed rivals that of other oilseeds, particularly rapeseed, flax, and sunflower [4]. 
Even though a hempseed industry infrastructure has been in place in Canada for 15 years, its stability may be severely tested by future hempseed production in the USA, as most Canadian production is exported to the USA. Once the USA begins production, potentially up to 30 states will anticipate making a profit on hemp by selling to the surrounding states. It may take 10 or 15 years for the industry in North America to readjust to the new paradigm. The uncertainty in yields, production costs, harvesting and processing equipment, and production characteristics will all increase the risk of hempseed production in the USA, until it becomes a standard crop [4].

\subsection{Cannabidiol}

The resin of $C$. sativa is usually dominated by CBD, THC or both. While most contemporary medicinal and recreational strains are predominantly dedicated to THC, CBD has considerable medicinal potential, indeed exceeding the likely value of THC [23]. Since the resin of hemp cultivars is dominated by CBD relative to THC, it is obvious that these varieties are a potential source of this invaluable cannabinoid. Because oilseed cultivars produce more flowers than fiber cultivars, and the inflorescences or infructescences are where most cannabinoids are produced, these cultivars are a logical source for CBD. Moreover, the residue after the seeds are harvested can be employed to salvage $\mathrm{CBD}$. The use of industrial hemp for the production of CBD has not received much consideration yet, although there is commercial interest in using field-grown plants for this purpose [23]. Since the hemp industry is already growing plants outdoors under license, with relatively small security requirements, why should it not also be permitted to harvest the CBD? The industrial hemp industry is not allowed to do so at the moment in most countries, but the large profit potential of CBD will very likely lead to harvest of this non-intoxicating cannabinoid. According to Bio-based News [82], in Europe alone "CBD has a minimum (annual) market penetration potential of $€ 24$ million ( $\$ 27.4$ billion)". At present, some biotypes that are not only rich in CBD but produce considerably more than conventional oilseed cultivars are being employed in some countries. Whether growing conventional oilseed cultivars for a dual crop (seeds and CBD) is a better strategy remains to be determined.

\subsection{Biomass}

It has been contended that hemp is notably superior to most crops in terms of biomass production, but van der Werf [83] observed that the annual dry matter yield of hemp (rarely approaching $20 \mathrm{t} / \mathrm{ha}$ ) is not exceptional compared to corn, beet or potato. Meijer et al. [84] also noted that there are constraints to the biomass production of hemp. However, most hemp varieties have been selected for production of fiber, not for biomass. Hemp has been rated on a variety of criteria as one of the best crops available to produce energy in Europe [85]. Hemp, especially the hurds, can be burned as is or processed into charcoal, methanol, methane or gasoline through pyrolysis (destructive distillation). Hemp could be used to create cellulosic-based ethanol [86,87]. González-García et al. [88] showed that ethanol derived from hemp hurds under some scenarios could be practical. However, conversion of hemp biomass into fuel or alcohol is impractical in areas where there are abundant supplies of wood, and energy can be produced relatively cheaply from a variety of sources. Prade et al. [89] concluded "The main competitors for hemp are maize and sugar beets for biogas production and the perennial crops willow, reed canary grass and Miscanthus for solid biofuel production. Hemp is an above-average energy crop with a large potential for yield improvements".

It is possible to convert hempseed oil to a biodiesel fuel by transesterification with methanol $[90,91]$ or ethanol [92], but with current prices and environmental incentives it is not economically competitive as a fuel. One advantage of hempseed oil is that it has a lower freezing point than saturated oils, better for biodiesel engines operating in cold environments [27]. In Europe, subsidization has been an important stimulus for the continuing development of biomass crops. In North America, biomass has not proven to have sustainable investment value, and the huge production of lumber waste and crop residues represents considerable competition for crops cultivated specifically for biomass. 


\section{Politics}

\subsection{Coupling and Decoupling of Hemp and Marijuana}

Marijuana's impact on hemp development in North America can be summarized as essentially catastrophic. Hemp was outlawed in North America nearly 80 years ago because it was confused with marijuana. Some believe, without any convincing evidence, that it was part of a paper manufacturer conspiracy to keep hemp from replacing timber [93]. An often-expressed concern over legalizing hemp in the USA is that marijuana plants would be hidden amongst hemp plants. However, today most marijuana is harvested from seedless plants (seedless marijuana is termed "sinsemilla") since the absence of seeds builds up the THC concentration, and knowledgeable marijuana growers would not grow their plants where they will be pollinated and produce seeds [23]. Both Canada and Europe have developed effective licensing systems for monitoring hemp production, and the absence of any reports linking hemp farms to the drug market over the past 20 years points out the success of such regulations.

Many government officials and citizens in the USA believe that the unprecedented massive support by non-farmers and politicians for legalization of hemp has less to do with it as it does with marijuana. Two surveys were conducted in the USA in the 1990s featuring hemp. When asked to agree or disagree with the statement "If we legalize industrial hemp, pretty soon we would legalize marijuana", 71\% of Kentucky residents who responded agreed with the statement [94]. Vermont residents were asked about the often mentioned concern that legalization of hemp production would inevitably lead to legalization of marijuana [95]. One third of respondents indicated that they were concerned or very concerned that this could happen. The Minnesota Department of Agriculture funded two surveys in 2014 regarding industrial hemp, a national survey of state departments of agriculture and a survey of Minnesota institutions of higher education [96]. Thirty-four out of 50 states responded to the survey, and one of the five questions focused on marijuana. Seventeen states replied that they had medical marijuana laws, and seven states replied that they had leniency laws for marijuana convictions. For the Minnesota colleges and universities survey, researchers were asked if they would participate in a pilot hemp program and to estimate the funding required. Half of the respondents said they would like to participate and estimated budgets of $\$ 20,000$ to $\$ 500,000$ would be required for hemp research.

It appears that many early industrial hemp advocates were motivated by the prospect of legalizing marijuana. The popular classic monograph promoting hemp and marijuana by Jack Herer first published in 1985 [93] has a very consistent theme that hemp is marijuana. Many now believe that the hemp industry has matured and is currently dominated by those who view hemp as the agricultural and industrial crop that it is, and see hemp legalization as a different issue from marijuana legalization [97]. Several of the USA state laws that have been recently proposed or passed, however, continue to link hemp to marijuana legislation. Also, the large number of states that have introduced hemp legislation, some if not many with inferior hemp growing environments, throw suspicion on the process. As noted by Caulkins et al. [98], "But it's hard to imagine that the passionate advocacy of industrial hemp is unrelated to its link to drug policy".

The political link between hemp and marijuana continues online, as marijuana-promoting websites often include hemp discussions. For example, www.NORML.org [99] lists information on state sponsored hemp trials under "Industrial uses of marijuana", and the site www.texashempcampaign. com [100] is strictly a pro-marijuana website. There is concern expressed by USDEA and others that efforts to legalize hemp are a front for individuals and organizations whose real aim is to see marijuana decriminalized [80]. While hemp-promoting websites clearly distinguish hemp issues from marijuana issues (e.g., [101-103]), marijuana-promoting websites often blur the distinction.

\subsection{Law Reviews}

Law Reviews or Law Journals are scholarly journals focusing on legal issues, containing articles, notes or comments to defend a particular point of view. There are numerous papers defending the 
viewpoint for legalization of industrial hemp in the USA, but none can be found with an opposing viewpoint. Pro-hemp Law Review discussions can be found from the following states: CA [104,105]; CO [106]; IN [107]; KY [108,109]; MO [110]; ND [111]; OK [112]; and OR [113]. There is a consistent enthusiastic theme throughout all these discussions: legalizing industrial hemp in the USA is in the public interest. Many of their arguments are supported by oft-repeated inaccurate or debatable statements. Most of these papers originate from individuals with little or no experience with field crops or crop production systems, calling their motives into question.

\section{Current Status of Industrial Hemp}

\subsection{Canada}

Canada has had a tradition of profitable oilseed products, including Canola, flaxseed, mustard, soybean, safflower, and sunflower, and therefore has the processing technology to take full advantage of new oilseed crops, such as hemp [4]. Canadian hemp production has been steadily increasing, after some market adjustments during the early years (Figure 7) [114], and almost all of this production is oilseed hemp. While some hemp for fiber has been grown, it cannot compete with China's production of low cost hemp textiles, or Europe's heavily subsidized hemp industry. Canada lacks a fiber crop industry and the processing technology that goes with it. Dual purpose crops for both fiber and oilseed have also been grown to a limited extent to produce modest seed yields combined with relatively low quality fiber production. Profitability of hempseed is much greater than that of fiber, and market forces are encouraging the emphasis on hempseed over fiber production.

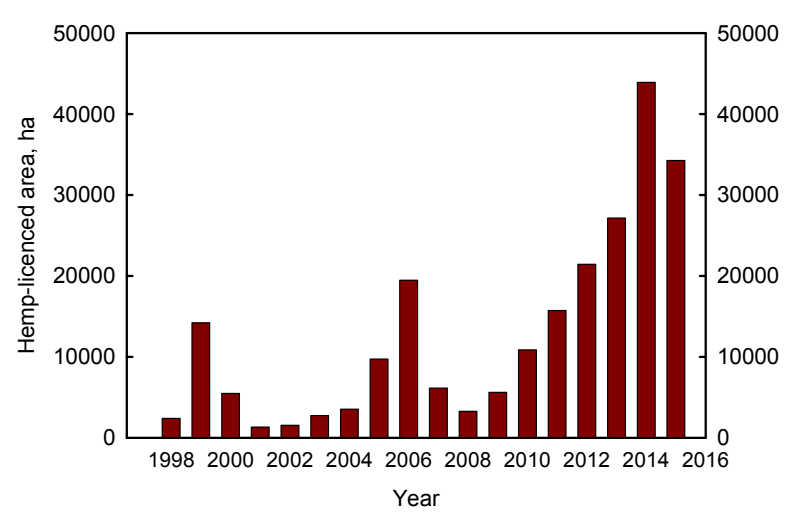

Figure 7. Hemp-licensed area (ha) in Canada since hemp production permits were available beginning in 1998. Source: [114].

\subsection{USA}

Beginning as early as 1999, states began to pass laws governing hemp cultivation (Table 2), assisted by the full support of the powerful American Farm Bureau Federation. As of October 2016, 30 states have passed laws on industrial hemp. Approximately half of the state laws permit farmers to be licensed to grow hemp. All hemp cultivation is contingent on approval from state agencies and from USDEA, as hemp remains linked with marijuana as a federally-controlled crop. Thirteen additional states are attempting to pass laws, and hemp legislation to-date has failed in six states. In three states, hemp legislation is contingent upon changes in federal law governing industrial hemp. All states are using the threshold concentration of $0.3 \%$ THC to legally distinguish hemp, except for West Virginia, which set the threshold at 1.0\% THC. Two states, Missouri and Utah, specifically allow the use of hemp extracts or CBD to treat individuals with epilepsy. Hawaii established a program to study the potential use of hemp as a phytoremediator and as a biofuel.

Ohio is the only state that has not attempted to pass hemp legislation to date, although several organizations are attempting to get the Medicinal Cannabis and Industrial Hemp constitutional 
amendment on the Ohio ballot in 2017. Approximately 300 industrial hemp bills have been proposed in state legislatures to date. The extraordinary widespread political support for a novel field crop is unprecedented and exceeds the actual potential of the crop. Eight states have conducted feasibility studies on hemp, with a range of very positive to negative conclusions on the economic feasibility of hemp production.

Table 2. Current status of industrial hemp legislation in USA.

\begin{tabular}{|c|c|c|c|}
\hline State Laws & Year & Study ${ }^{1}$ & Provisions \\
\hline Alabama & 2016 & No & Research only \\
\hline Arizona & 2015 & In progress & Study authorized \\
\hline Arkansas & 1999 & Yes & Study authorized \\
\hline California & 2013 & In progress & License farmers ${ }^{2}$ \\
\hline Colorado & 2013 & No & License farmers \\
\hline Connecticut & 2015 & In progress & Legalize hemp \\
\hline Delaware & 2014 & No & Research only \\
\hline Hawaii & 2014 & Yes & Research only \\
\hline Illinois & 2014 & Yes & Research only \\
\hline Indiana & 2014 & No & License farmers \\
\hline Kentucky & 2013 & Yes & License farmers \\
\hline Maine & 2009 & Yes & License farmers ${ }^{2}$ \\
\hline Maryland & 2014 & No & License farmers ${ }^{2}$ \\
\hline Michigan & 2014 & No & Research only \\
\hline Minnesota & 2015 & No & Research only \\
\hline Montana & 2001 & No & License farmers \\
\hline Nebraska & 2014 & No & Research only \\
\hline Nevada & 2015 & No & Research only \\
\hline New Hampshire & 2015 & In progress & Research only \\
\hline New York & 2014 & No & Research only \\
\hline North Carolina & 2015 & No & Research only \\
\hline North Dakota & 1999 & Yes & License farmers \\
\hline Oregon & 2009 & Yes & License farmers \\
\hline South Carolina & 2014 & No & License farmers \\
\hline Tennessee & 2014 & No & License farmers \\
\hline Utah & 2014 & No & Research only \\
\hline Vermont & 2013 & Yes & License farmers \\
\hline Virginia & 2015 & No & Research only \\
\hline Washington & 2016 & In progress & Research only \\
\hline West Virginia & 2002 & No & License farmers \\
\hline Legislation & Year & Study & Status of Legislation \\
\hline Alaska & 2016 & No & Sponsored \\
\hline Arizona & 2015 & No & Stalled \\
\hline Florida & 2016 & No & Failed \\
\hline Georgia & 2016 & No & Sponsored \\
\hline Idaho & 2007 & No & Failed \\
\hline Iowa & 2016 & No & Stalled \\
\hline Kansas & 2016 & No & Failed \\
\hline Louisiana & 2016 & No & Sponsored \\
\hline Massachusetts & 2016 & No & Stalled \\
\hline Mississippi & 2015 & No & Failed \\
\hline Missouri & 2016 & Yes & Sponsored \\
\hline New Jersey & 2014 & No & Stalled \\
\hline New Mexico & 2016 & No & Stalled \\
\hline Oklahoma & 2014 & No & Stalled \\
\hline Pennsylvania & 2016 & No & Sponsored \\
\hline Rhode Island & 2016 & No & Sponsored ${ }^{3}$ \\
\hline South Dakota & 2016 & No & Failed \\
\hline Texas & 2016 & No & Sponsored \\
\hline Wisconsin & 2016 & No & Failed \\
\hline
\end{tabular}

${ }^{1}$ Conducted or conducting a feasibility study on hemp; ${ }^{2}$ Provisions of the hemp law do not become operative unless authorized by the federal government; ${ }^{3}$ Industrial hemp is included in proposed marijuana legislation.

\subsubsection{State Reports on Hemp}

In general, state reports provide a history of hemp in the USA and a summary of the agronomy of hemp. They also describe the versatility of hemp for purposes such as construction materials, 
paper, textiles, plastics, food products, and biomass feedstock. Several reports [5,55] strongly focus on fiber production, particularly in the Pacific Northwest. The North Dakota study [72] focuses on oilseed production. Based upon the evidence presented, Illinois Task Force members concluded that there is potential for industrial hemp to be an important alternative crop [81]. A Kentucky report [75] concluded that there are a number of specialty or niche markets for hemp products, and that the economic impact for Kentucky would be greatest if the state becomes the main source for certified hempseed in the USA.

A report on the economic viability and political concerns for industrial hemp generated for the Hawaiian legislature [115] implies that hemp has high profitability, as well as numerous sustainable agriculture advantages. The Hawaiian paper also points to the large number of groups, companies and individuals who are supporting hemp cultivation as evidence against the common misconception that "The effort to legalize hemp is a ruse to legalize the drug". In general, most state studies are very positive about the potential of hemp in their state, but studies tend to focus on fiber uses and not seed or pharmaceutical uses, and most of these studies are out of date. State hemp studies in Maine [116] and Arkansas [117] that do not have very positive conclusions are not included under state-sponsored hemp trial lists on websites such as www.NORML.org [99]. Environmental or economic concerns limit the potential of hemp, according to Maine and Arkansas reports.

\subsubsection{Possible Scenarios for the USA}

Figure 8 shows three possible scenarios for the USA, depending on the ability of the North American hemp market to expand to absorb production. Even the most optimistic scenario (A) results in about half of the states failing in their attempt to establish a hemp industry in their state. From an economic investment standpoint, USA entrepreneurs and states appear to be assuming the market will be supply-driven, not demand-driven. The most likely scenario may lie between " $\mathrm{A}$ " and "B", with a small niche market for hemp fiber, coupled with a considerably larger market for hempseed products. Any of these scenarios (Figure 8) will have at least a short term negative impact on the Canadian hemp industry.

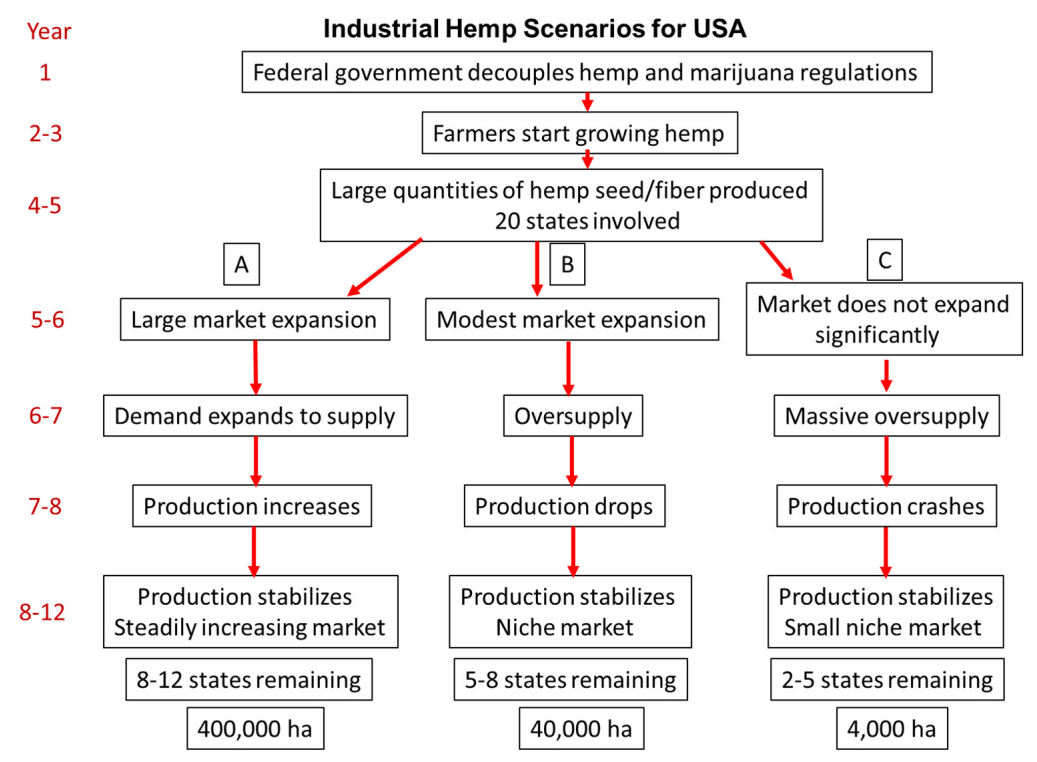

Figure 8. Possible industrial hemp scenarios in the USA.

\section{Summary}

The promise of industrial hemp is somewhere between "Hemp is just a stalking horse for marijuana" and "Hemp can save the planet". There is no other example in history of a novel field 
crop being so greatly impacted by socio-politics. While interest in industrial hemp in Canada is relatively well matched to its potential as an oilseed crop, the current hype over industrial hemp in the USA exceeds the actual short-term potential of this field crop. One of the primary reasons for excess enthusiasm in the USA appears to be the tight link between many marijuana supporters and the movement to reintroduce hemp cultivation in the USA - many hoping that legal hemp cultivation will help pave the way to decriminalization of marijuana. There are clearly two camps regarding hemp promotion in the USA and it is impossible to completely separate them or quantify their relative proportions.

Although a small amount of hemp is grown for fiber in Canada, the fiber market has a much more limited potential compared to oilseed in North America. European hemp production, initially mostly fiber but now with significant hempseed production, is maintained through government subsidies. China, where hemp originated, has the capability to produce large quantities of very competitively priced hemp fiber, primarily due to inexpensive labor. While there will likely be a small, dedicated niche market for hemp fiber in North America, there is insufficient evidence to suggest that a large market demand will materialize to meet a large supply. The hemp oilseed market is stable and steadily increasing in Canada, and the USA has the potential to establish a similar market once industrial hemp is legally distinguished from marijuana and declassified as a Schedule 1 controlled substance.

Like all grain crops grown in the USA and Canada, hemp production demands relatively intensive management for success, and many potential industrial hemp growers in the USA do not appreciate the level of crop management required. Seedbed conditions, seeding rates, dates, and harvest dates are all impacted by the hemp germplasm used. Grain crop production is not for the hobby farmer, and the four-year crop rotation necessary to minimize pest buildup requires a significant supply of cropland. After legalization of hemp in the USA, hemp farmers may face the serious economic consequences of oversupply, as did many farmers who were encouraged to establish switchgrass in anticipation of the cellulosic ethanol industry over the past 10 years. The North American hemp oilseed market will quickly become saturated if production is initiated in multiple states. Hemp fiber production will remain a small niche market, as demand is likely to remain modest and will face stiff competition from both China and the EU. Hemp oilseed supply and demand will eventually recover from the influx of USA hemp oilseed, but may be disruptive to farm economies for an extended period.

Canada has successfully established and maintained stable/increasing hemp oilseed production after the first 8 years of market adjustment. Canadian society appears to clearly understand the distinction between industrial hemp and marijuana, and the hemp industry in Canada seems relatively immune to marijuana politics. United States society, on the other hand, is having a difficult time separating hemp from marijuana politics. The widespread and aggressive championing of industrial hemp overshadows the significant legitimate potential of hemp as a field crop in the USA, with numerous marijuana advocates promoting declassification of hemp.

More than 30 US states could attempt to establish an industrial hemp crop industry following deregulation, greatly increasing the potential for hemp market chaos in North America. Since the drive for hemp production is coming from individual states, there is little consideration of basic supply and demand economics. Oversupply is highly likely, resulting in a production crash much more severe than was observed in Canada during the early years of the industry. The most opportunistic scenario for hemp in North America is oilseed production coupled with CBD extraction from hemp stover and/or from floral parts of oilseed cultivars for pharmaceutical uses. Markets for small acreage crops are fragile, and good advice for North American farmers interested in hemp production is to identify buyers and a selling price before planting the crop.

Conflicts of Interest: The authors declare no conflict of interest.

\section{References}

1. Industrialhemp.net. Available online: http://www.industrialhemp.net/ (accessed on 11 November 2016). 
2. Small, E. Cannabis: A Complete Guide; CRC Press: Boca Raton, FL, USA, 2016; in press.

3. Small, E.; Cronquist, A. A practical and natural taxonomy for Cannabis. Taxon 1976, 25, 405-435. [CrossRef]

4. Miller, R.L. Hemp as a Crop for Missouri Farmers: Markets, Economics, Cultivation, Law. Report to Agriculture Task Force, Missouri House of Representatives. 1991. Available online: www.naihc.org/hemp_ information/content/millerhemp.html (accessed on 14 October 2016).

5. Ehrensing, D.T. Feasibility of Industrial Hemp Production in the United States Pacific Northwest; Station Bulletin 681; Oregon State University: Corvallis, OR, USA, 1998.

6. Small, E.; Marcus, D. Hemp-A new crop with new uses for North America. In Trends in New Crops and New Uses; Janick, J., Whipkey, A., Eds.; ASHS Press: Alexandria, Egypt, 2002; pp. 284-326.

7. USDA-NRCS. Plants Database. Natural Resource and Conservation Service, U.S. Department of Agriculture. Available online: www.plants.usda.gov/core/profile?symbol=casa3 (accessed on 14 October 2016).

8. Carus, M.; Sarmento, L. The European Hemp Industry: Cultivation, processing and applications for fibres, shivs, seed and flowers. European Industrial Hemp Association, May 2016; pp. 1-9. Available online: http: / / eiha.org/media/2016/05/16-05-17-European-Hemp-Industry-2013.pdf (accessed on 8 November 2016).

9. Small, E.; Pocock, T.; Cavers, P.B. The biology of Canadian weeds. 119. Cannabis sativa L. Can. J. Plant Sci. 2003, 83, 217-237.

10. Carus, M.; Karst, S.; Kauffmann, A.; Hobson, J.; Bertucelli, S. The European Hemp Industry: Cultivation, Processing and Applications for Fibres, Shives and Seeds; European Industrial Hemp Association: Hürth, Germany, 2013; pp. 1-9.

11. Cochran, M.J.; Windham, T.E.; Moore, B. Feasibility of Industrial Hemp Production in Arkansas; Report SP102000; Department of Agricultural Economics and Agribusiness, University of Arkansas, Division of Agriculture: Fayetteville, AR, USA, 2000.

12. FAOSTAT3. Statistics Division, Food and Agriculture Organization of the United Nations. Available online: http:/ / faostat3.fao.org. (accessed on 14 October 2016).

13. Small, E. Evolution and classification of Cannabis sativa (marijuana, hemp) in relation to human utilization. Bot. Rev. 2015, 81, 189-294. [CrossRef]

14. Da Silva Vieira, R.; Canaveira, P.; da Simoes, A.; Domingos, T. Industrial hemp or eucalyptus paper? Int. J. Life Cycle Assess. 2010, 15, 368-375. [CrossRef]

15. Suardana, N.P.G.; Piao, Y.; Lim, J.K. Mechanical properties of hemp fibres and hemp/PP composites: Effects of chemical surface treatment. Mater. Phys. Mech. 2011, 11, 1-8.

16. Yallew, T.B.; Kumar, P.; Singh, I. Sliding behaviour of woven industrial hemp fabric reinforced thermoplastic polymer composites. Int. J. Plast. Technol. 2015, 19, 347-362. [CrossRef]

17. Domke, P.V.; Mude, V.D. Natural fiber reinforced building materials. IOSR J. Mech. Civ. Eng. 2015, 12, 104-107.

18. Duffy, E.; Lawrence, M.; Walker, P. Hemp-lime: Highlighting room for improvement. Civ. Environ. Res. 2013, 4, 16-21.

19. Walker, R.; Pavia, S.; Mitchell, R. Mechanical properties and durability of hemp-lime concretes. Constr. Build. Mater. 2014, 61, 340-348. [CrossRef]

20. Bouloc, P. The uses of hemp for domestic animals. In Hemp: Industrial Production and Uses; Bouloc, P., Allegret, S., Arnaud, L., Eds.; CAB International: Wallingford, UK; Boston, MA, USA, 2013; pp. $260-262$.

21. U.S. International Trade Commission (USITC). U.S. Import and Export Data on Dataweb; U.S. International Trade Commission: Washington, DC, USA, 2016. Available online: www.dataweb.usitc.gov (accessed on 14 October 2016).

22. Huang, H.T. Science and Civilization in China, Vol. 6: Biology and Biological Technology, Part V: Fermentation and Food Science; Cambridge University: Cambridge, UK, 2000.

23. Schultes, R.E. Random thoughts and queries on the botany of Cannabis. In The Botany and Chemistry of Cannabis; Joyce, R.B., Curry, S.H., Eds.; J. \& A. Churchill: London, UK, 1970; pp. 11-38.

24. Laakkonen, T.T.; Callaway, J.C. Update on FIN-314. J. Int. Hemp Assoc. 1998, 5, 34-35.

25. Matthäus, B.; Brühl, L. Virgin hemp seed oil: An interesting niche product. Eur. J. Lipid Sci. Technol. 2008, 110, 655-661. [CrossRef]

26. Mustafa, A.F.; McKinnon, J.J.; Christensen, D.A. The nutritive value of hemp meal for ruminants. Can. J. Anim. Sci. 1999, 79, 91-95. [CrossRef] 
27. Oomah, B.D.; Busson, M.; Godfrey, D.V.; Drover, J.C.G. Characteristics of hemp (Cannabis sativa L.) seed oil. Food Chem. 2002, 76, 33-43.

28. Callaway, J.C.; Pate, D.W. Hempseed oil. In Gourmet and Health-Promoting Specialty Oils; Moreau, R., Kamal-Eldin, A., Eds.; AOCS Press: Urbana, IL, USA, 2009; pp. 185-214.

29. Aladic, K.; Jarni, K.; Barbir, T.; Vidovic, S.; Vladic, J.; Bilic, M.; Jokic, S. Supercritical $\mathrm{CO}_{2}$ extraction of hemp (Cannabis sativa L.) seed oil. Ind. Crops Prod. 2015, 76, 472-478. [CrossRef]

30. Callaway, J.C. Hempseed as a nutritional resource: An overview. Euphytica 2004, 140, 65-72. [CrossRef]

31. Leson, G.; Pless, P. Hemp seed and hemp oil. In Cannabis and Cannabinoids. Pharmacology, Toxicology, and Therapeutic Potential; Grotenhermen, F., Russo, E., Eds.; Haworth Integrative Healing Press: Binghamton, NY, USA, 2002; pp. 411-425.

32. Deferne, J.-L.; Pate, D.W. Hemp seed oil: A source of valuable essential fatty acids. J. Int. Hemp Assoc. 1996, $3,4-7$.

33. Teh, S.-S.; Birch, J. Physicochemical and quality characteristics of cold-pressed hemp, flax and canola seed oils. J. Food Comp. Anal. 2013, 30, 26-31. [CrossRef]

34. Mölleken, H.; Mothes, H.; Dudek, S. Quality of hemp fruits and hemp oil in relation to the maturity of the fruits. In Proceedings of the Bioresource Hemp \& Other Fibre Crops: Proceedings of the Symposium, Wolfsburg, Germany, 13-16 September 2000; Nova Institute: Hürth, Germany, 2000.

35. Vonapartis, E.; Aubin, M.-P.; Seguin, P.; Mustafa, A.F.; Charron, J.-B. Seed composition of ten industrial hemp cultivars approved for production in Canada. J. Food Comp. Anal. 2015, 39, 8-12. [CrossRef]

36. Small, E.; Marcus, D. Hemp germplasm trials in Canada. Irregularly paginated. In Proceedings of the Third International Symposium Bioresource Hemp, Wolfsburg, Germany, 13-16 September 2000; Nova Corporation: Hürth, Germany, 2000.

37. Chen, T.; He, J.; Zhang, J.; Zhang, H.; Qian, P.; Hao, J.; Li, L. Analytical characterization of hempseed (seed of Cannabis sativa L.) oil from eight regions in China. J. Diet. Suppl. 2010, 7, 117-129. [PubMed]

38. Kriese, U.; Schumann, E.; Weber, W.E.; Beyer, M.; Brühl, L.; Matthäus, B. Oil content, tocopherol composition and fatty acid patterns of the seeds of 51 Cannabis sativa L. genotypes. Euphytica 2004, 137, 339-351. [CrossRef]

39. Anwar, F.; Latif, S.; Ashraf, M. Analytical characterization of hemp (Cannabis sativa) seed oil from different agro-ecological zones of Pakistan. J. Am. Oil Chem. Soc. 2006, 83, 323-329. [CrossRef]

40. Mihoc, M.; Pop, G.; Alexa, E.; Radulov, I. Nutritive quality of Romanian hemp varieties (Cannabis sativa L.) with special focus on oil and metal contents of seeds. Chem. Cent. J. 2012, 6, 122-133. [CrossRef] [PubMed]

41. Callaway, J. Basic information on FINOLA Agronomy for 2016. Available online: http://finola.fi/Finola_ basic_farming_info_2016.pdf (accessed on 10 November 2016).

42. Official Journal of the European Union. Decisions. Off. J. Eur. Union 2016, 59, 7.

43. Mölleken, H.; Theimer, R.R. Survey of minor fatty acids in Cannabis sativa L. fruits of various origins. J. Int. Hemp Assoc. 1997, 4, 13-17.

44. De Meijer, E. The chemical phenotypes (chemotypes) of Cannibis. In Handbook of Cannabis; Pertwee, R.G., Ed.; Oxford University Press: Oxford, UK, 2014; pp. 89-110.

45. Levin, D.A. The role of trichomes in plant defense. Q. Rev. Biol. 1973, 48, 3-15. [CrossRef]

46. Wagner, G.J.; Wang, E.; Shepherd, W. New approaches for studying and exploiting an old proturberance, the plant trichome. Ann. Bot. 2004, 93, 3-11. [CrossRef] [PubMed]

47. Potter, D.J. Cannabis horticulture. In Handbook of Cannabis; Pertwee, R.G., Ed.; Oxford University Press: Oxford, UK, 2014; pp. 65-88.

48. Small, E.; Naraine, S.G.U. Size matters: Evolution of large drug-secreting resin glands in elite pharmaceutical strains of Cannabis sativa (marijuana). Genet. Resour. Crop Evol. 2016, 63, 349-359. [CrossRef]

49. Grotenhermen, F.; Karus, M. Industrial hemp is not marijuana: comments on the drug potential of fiber Cannabis. J. Int. Hemp Assoc. 1998, 5, 96-101.

50. Pertwee, R.G. The diverse $\mathrm{CB}_{1}$ and $\mathrm{CB}_{2}$ receptor pharmacology of three plant cannabinoids: $\Delta^{9}$-tetrahydrocannabinol, cannabidiol and $\Delta^{9}$-tetrahydrocannabivarin. Br. J. Pharmacol. 2008, 153, 199-215. [CrossRef] [PubMed]

51. Piomelli, D.; Russo, E.B. The Cannabis sativa Versus Cannabis indica Debate: An Interview with Ethan Russo, MD. Cannabis Cannabinoid Res. 2016, 1.1, 44-46. [CrossRef]

52. Mechoulam, R.; Hanus, L. Cannabidiol: An overview of some chemical and pharmacological aspects. Part I: Chemical aspects. Chem. Phys. Lipids 2002, 121, 35-43. [CrossRef] [PubMed] 
53. Pertwee, R.G. The pharmacology and therapeutic potential of cannabidiol. In Cannabinoids; Di Marzo, V., Ed.; Kluwer Academic/Plenum Publishers: New York, NY, USA, 2004; pp. 32-83.

54. Pertwee, R.G. Pharmacological and therapeutic targets for $\Delta^{9}$-tetrahydrocannabinol and cannabidiol. Euphytica 2004, 140, 73-82. [CrossRef]

55. Small, E. The Species Problem in Cannabis: Science and Semantics. Volume 2, Semantics; Corpus: Toronto, ON, Canada, 1979.

56. Rock, E.M.; Sticht, M.A.; Parker, L.A. Effect of phytocannabinoids on nausea and vomiting. In Handbook of Cannabis; Pertwee, R.G., Ed.; Oxford University Press: Oxford, UK, 2014; pp. 435-454.

57. Casler, M.D.; Vogel, K.P.; Harrison, M. Switchgrass germplasm resources. Crop Sci. 2015, 55, $2463-2478$. [CrossRef]

58. Cherney, J.H.; Cherney, D.J.R.; Akin, D.E.; Axtell, J.D. Potential of brown-midrib, low-lignin mutants for improving forage quality. In Advances in Agronomy; Sparks, D.L., Ed.; Academic Press, Inc.: Orlando, FL, USA, 1991; Chapter 4, Volume 46, pp. 157-198.

59. Amato, J.A. The Great Jerusalem Artichoke Circus: The Buying and Selling of the Rural American Dream; University of Minnesota Press: Minneapolis, MN, USA, 1993.

60. McMinimy, M.A. Biomass Crop Assistance Program (BCAP): Status and Issues; Congressional Research Service Report R41296; CRS: Washington, DC, USA, 2015.

61. Vantreese, V.L. Industrial Hemp: Global Markets and Prices; Department of Agricultural Economics, University of Kentucky: Lexington, KY, USA, 1997.

62. Williams, D.W.; Mundell, R. Agronomic Recommendations for Industrial Hemp Production in Kentucky-2016; University of Kentucky: Lexington, KY, USA, 2016; Available online: http:/ /www.kyagr.com/marketing/ documents/HEMP_UK-agronomic-recommendations.pdf (accessed on 14 October 2016).

63. Meints, J. The hemp plant, humandkind's savior-50,000 uses and counting. 23 January 2007. Available online: www.voteindustrialhemp.com/ (accessed on 10 November 2016).

64. Baxter, W.J.; Scheifele, G. Growing Industrial Hemp in Ontario; Factsheet \#67; Ontario Ministry of Agriculture, Food and Rural Affairs: Guelph, ON, Canada, 2009. Available online: http://www.omafra.gov.on.ca/ english/crops/facts/00-067.htm (accessed on 14 October 2016).

65. Desanlis, F.; Cerruti, N.; Warner, P. Hemp agronomics and cultivation. In Hemp: Industrial Production and Uses; Bouloc, P., Allegret, S., Arnaud, L., Eds.; CAB International: Wallingford, UK; Boston, MA, USA, 2013; pp. 98-124.

66. Montford, S.; Small, E. Measuring harm and benefit: The biodiversity friendliness of Cannabis sativa L. Glob. Biodivers. 1999, 8, 2-13.

67. Montford, S.; Small, E. A comparison of the biodiversity friendliness of crops with special reference to hemp (Cannabis sativa L.). J. Int. Hemp Assoc. 1999, 6, 53-63.

68. Bouloc, P.; Van Der Werf, H.M.G. The role of hemp in sustainable development. In Hemp: Industrial Production and Uses; Bouloc, P., Allegret, S., Arnaud, L., Eds.; CAB International: Wallingford, UK; Boston, MA, USA, 2013; pp. 278-289.

69. Kerckhoffs, H.; Kavas, Y.; Millner, J.; Anderson, C.; Kawana-Brown, E. Industrial hemp in New Zealand-Potential for cash cropping for a better environment in the Taranaki region. In Proceedings of the 17th Australian Society of Agronomy Conference, Hobart, Australia, 20-24 September 2015.

70. Riddlestone, S.; Desai, P.; Evans, M.; Skyring, A. Bioregional Fibers, the Potential for a Sustainable Regional Paper and Textile Industry Based on Flax and Hemp; Bioregional Development Group, Sutton Ecology Centre: Carshalton, UK, 1994.

71. Gehl, D. A Summary of Hemp Research in Canada Conducted by the Fibre Division of Agriculture Canada, 1923-1942; Agriculture and Agri-Food Canada: Indian Head, SK, Canada, 1995.

72. McNulty, S. (Ed.) Report to the Governor's Hemp and Related Fiber Crops Task Force; Commonwealth of Kentucky: Frankfort, KE, June 1995; Available online: http:/ / www.globalhemp.com/1995/06/report-to-the-governorshemp-and-related-fiber-crops-task-force.html (accessed on 14 October 2016).

73. Kraenzel, D.G.; Petry, T.; Nelson, B.; Anderson, M.J.; Mathern, D.; Todd, R. Industrial Hemp as an Alternative Crop in North Dakota: A White Paper Study of the Markets, Profitability, Processing, Agronomics and History; Agricultural Economics Report No. 402; The Institute for Natural Resources and Economic Development, North Dakota State University: Fargo, ND, USA, 1998. 
74. Marcus, D. Commercial Hemp Cultivation in Canada: An Economic Justification. 1998. Available online: http://naihc.org/hemp_information/content/dmarcustx.html (accessed on 14 October 2016).

75. Pinfold Consulting. A Maritime Industrial Hemp Product Marketing Study. Prepared for Nova Scotia Agriculture and Marketing (Marketing and Food Industry Development), and New Brunswick Agriculture \& Rural Development (Marketing and Business Development). G. Pinfold Consulting Economists Ltd. and J. White, InfoResults Ltd. Irregularly Paginated. 1998. Available online: http:/ / www.novascotia.ca/agri/ marketing/research/hempms02.shtml (accessed on 14 October 2016).

76. Thompson, E.C.; Berger, M.C.; Allen, S.N. Economic Impact of Industrial Hemp in Kentucky; Center for Business and Economic Research, University of Kentucky: Lexington, KY, USA, 1998.

77. Johnson, P. Industrial hemp: A critical review of claimed potential for Cannabis sativa. Tappi J. 1999, 82, 77.

78. USDA-ERS. Industrial Hemp in the United States: Status and Market Potential, AGES001E. January 2000; Economic Research Service, U.S. Department of Agriculture. Available online: http:/ /www.ers.usda.gov/ publications/ages001e/ages001em.pdf (accessed on 14 October 2016).

79. Fortenbery, T.R.; Bennett, M. Opportunities for commercial hemp production. Rev. Agric. Econ. 2004, 26, 97-117. [CrossRef]

80. Robbins, L.; Snell, W.; Halich, G.; Maynard, L.; Dillon, C.; Spalding, D. Economic Considerations for Growing Industrial Hemp: Implications for Kentucky's Farmers and Agricultural Economy; Department of Agricultural Economics, University of Kentucky: Lexington, KY, USA, 2013.

81. Johnson, R. Hemp as an Agricultural Commodity. CRS Report RL32725; Congressional Research Service: Washington, D.C., 26 January 2016; Available online: http:/ / nationalaglawcenter.org/wp-content/uploads / assets/crs/RL32725.pdf (accessed on 14 October 2016).

82. Illinois Industrial Hemp Investigative and Advisory Task Force. Report Submitted to the Illinois Hours of Representatives. 26 January 2000. Available online: http://www.globalhemp.com/2000/01/illinoisindustrial-hemp-investigative-and-advisory-task-force-report.html (accessed on 14 October 2016).

83. Bio-Based News. Growing Markets for Hemp Food and Pharmaceuticals_Potential Billion $€$ Markets in Europe. 25 April 2016. Available online: www.news.bio-based.eu/growing-markets-for-hemp-food-andpharmaceuticals-potential-billion-e-markets-in-europe/ (accessed on 14 October 2016).

84. Van der Werf, H.M.G. Hemp facts and hemp fiction. J. Int. Hemp Assoc. 1994, 1, 58-59.

85. Meijer, W.J.M.; Vanderwerf, H.M.G.; Mathijssen, E.W.J.M.; Vandenbrink, P.W.M. Constraints to dry-matter production in fiber hemp. Eur. J. Agron. 1995, 4, 109-117. [CrossRef]

86. Biewinga, E.E.; Van der Bijl, G. Sustainability of Energy Crops in Europe. A Methodology Developed and Applied; Report No. 234; Centre for Agriculture and Environment: Utrecht, The Netherlands, 1996.

87. Kuglarz, M.; Alvarado-Morales, M.; Karakashev, D.; Angelidaki, I. Integrated production of cellulosic bioethanol and succinic acid from industrial hemp in a biorefinery concept. Bioresour. Technol. 2016, 200, 639-647. [CrossRef] [PubMed]

88. Sipos, B.; Kreuger, E.; Svensson, S.E.; Réczey, K.; Björnsson, L.; Guido, Z. Steam pretreatment of dry and ensiled industrial hemp for ethanol production. Biomass Bioenergy 2010, 34, 1721-1731. [CrossRef]

89. González-García, S.; Luo, L.; Moreira, M.T.; Feijoo, G.; Huppes, G. Life cycle assessment of hemp hurds use in second generation ethanol production. Biomass Bioenergy 2012, 36, 268-279. [CrossRef]

90. Prade, T.; Svensson, S.E.; and Mattson, J.E. Energy balances for biogas and solid biofuel production from industrial hemp. Biomass Bioenergy 2012, 40, 36-52. [CrossRef]

91. Ragit, S.S.; Mohapatra, S.K.; Gill, P.; Kundu, K. Brown hemp methyl ester: Transesterification process and evaluation of fuel properties. Biomass Bioenergy 2012, 41, 14-20. [CrossRef]

92. Li, S-Y.; Stuart, J.D.; Li, Y.; Parnas, R.S. The feasibility of converting Cannabis sativa L. oil into biodiesel. Bioresour. Technol. 2010, 101, 8457-8460.

93. Ragit, S.S.; Mohapatra, S.K.; Kundu, K.; Karmakar, R. Methanolysis and ethanolysis of raw hemp oil: Biodiesel production and fuel characterization. Int. J. Eng. Res. Technol. 2013, 2.

94. Herer, J. Hemp and the Marijuana Conspiracy: The Emperor Wears No Clothes, 10th ed.; Ahha Publishing: Austin, TX, USA, 1996.

95. Survey Research Center. Survey Research Center Data Archive, University of Kentucky. 1995 Kentucky Spring Poll. Available online: www.research.uky.edu/survey/dataarchive.html (accessed on 14 October 2016). 
96. Chan Halbrendt, C.; Wang, Q.; Mole, M.C. Alternative agricultural strategies in Vermont: The case of industrial hemp. In Proceedings of the Vermont Agricultural Economic Development Conference, South Burlington, VT, USA, 16 December 1996.

97. Cortilet, A. Industrial Hemp Research. Report to the Minnesota Department of Agriculture. Minnesota Law 2014: HF3172-3 (SF2785); Chapter 312: Article 12; Section 3. 15 January 2015. Available online: www.mda.state.mn.us (accessed on 14 October 2016).

98. West, D.P. Hemp and Marijuana: Myths \& Realities. North American Industrial Hemp Council, Inc., 1998. Available online: www.naihc.org (accessed on 14 October 2016).

99. Callaway, J. Current status of FINOLA in the EU. Available online: http://finola.fi/DEFRA_prohibition_ Cancelled_Oct2016.pdf (accessed on 10 November 2016).

100. NORML and the NORML Foundation. Industrial use of marijuana. Washington DC, USA. Available online: http://norml.org/marijuana/industrial (accessed on 10 November 2016).

101. Texas hemp Campaign. Austin, TX, USA. Available online: http://texashempcampaign.com/ (accessed on 14 October 2016).

102. North American Industrial Hemp Council. Madison, WI, USA. Available online: http://naihc.org/ (accessed on 11 November 2016).

103. Hempethics. Oroville, CA, USA. Available online: http://hempethics.weebly.com/ (accessed on 11 November 2016).

104. Caulkins, J.P.; Hawken, A.; Kilmer, B.; Kleiman, M.A.R. Marijuana Legalization: What Everyone Needs to Know; Oxford University Press: New York, NY, USA, 2012.

105. Brady, T.C. The argument for the legalization of industrial hemp. San Joaquin Agric. Law Rev. 2003, 13, 85-108.

106. Kolosov, C.A. Evaluating the public interest: Regulation of industrial hemp under the Controlled Substances Act. UCLA Law Rev. 2009, 57, 237-274.

107. Thedinger, S. Prohibition in the United States: International and U.S. regulation and control of industrial hemp. Colo. J. Int. Environ. Law Policy 2006, 17, 419-446.

108. Keller, N.M. The legalization of industrial hemp and what it could mean for Indiana's biofuel industry. Indiana Int. Comp. Law Rev. 2013, 23, 555-590.

109. Dwyer, S.D. The hemp controversy: Can industrial hemp save Kentucky. Ky. Law J. 1997, 86, 1143-1182.

110. Rogers, V. The future of hemp in Kentucky. Ky. J. Equine Agric. Nat. Resour. Law 2012, 4, 479-500.

111. Shepherd, C.D. Lethal concentration of power: How the D.E.A. acts improperly to prohibit the growth of the industrial hemp. UMKC Law Rev. 1999, 68, 239-262.

112. Duppong, T.A. Industrial Hemp: How the classification of industrial hemp as marijuana under the Controlled Substances Act has caused the dream of growing industrial hemp in North Dakota to go up in smoke. N. D. Law Rev. 2009, 85, 403-434.

113. Lash, R. Industrial hemp: The crop for the Seventh Generation. Am. Indian Law Rev. 2002, 27, $313-356$. [CrossRef]

114. Moran, C.N. Industrial hemp: Canada exports, United States imports. Fordham Environ. Law Rev. 2015, 26, 383-449.

115. Health Canada, Office of Controlled Substances. Ottawa, Ontario, Canada, 2016. Available online: www.hcsc.gc.ca (accessed on 14 October 2016).

116. Roth-Li, G. Industrial Hemp (Cannabis sativa)_Economic Viability and Political Concerns; White Paper Prepared for Representative Cynthia Thielen; Hawaiian State Legislature: Honolulu, HI, USA, 1996. Available online: http://www.globalhemp.com/1996/04/hawaiian-industrial-hemp-report.html (accessed on 14 October 2016).

117. MAFES. An Assessment of Industrial Hemp Production in Maine; Maine Agricultural and Forest Experiment Station: Orono, ME, USA, 2016; Available online: www.votehemp.com/PDF/ME_Hemp_Study_2006.pdf (accessed on 14 October 2016).

(C) 2016 by the authors; licensee MDPI, Basel, Switzerland. This article is an open access article distributed under the terms and conditions of the Creative Commons Attribution (CC-BY) license (http://creativecommons.org/licenses/by/4.0/). 